\title{
Phylogenetic Analysis and Biogeography of the Nocturnal Hornets, Provespa (Insecta: Hymenoptera: Vespidae: Vespinae)
}

\author{
Fuki Saito $^{1,2}$ and Jun-ichi Kojima ${ }^{2}$ \\ ${ }^{1}$ Postdoctoral Fellow of the Japan Society for the Promotion of Science \\ E-mail: fsfsaito@gmail.com \\ ${ }^{2}$ Natural History Laboratory, Faculty of Science, Ibaraki University, Mito, 310-8512 Japan
}

(Received 30 March 2010; Accepted 21 September 2010)

\begin{abstract}
Relationships among the three species of nocturnal hornet of the genus Provespa Ashmead, 1903 are cladistically analyzed based on adult morphological characters and mitochondrial DNA sequence data. Monophyly of Provespa is supported and the species relationships are expressed as $(P$. barthelemyi $+(P$. anomala $+P$. nocturna)). Provespa barthelemyi (Du Buysson, 1905) is distributed mainly in the southeastern part of the Asian continent from eastern India to Indochina, while $P$. nocturna Vecht, 1935 and $P$. anomala (Saussure, 1854) occur mainly in Sumatra, Borneo, and the southern part of the Malay Peninsula. The speciation and biogeography of Provespa are briefly discussed, with reference to a supposed vicariance event around the Isthmus of Kra.

Key Words: Vespidae, Vespinae, Provespa, phylogeny, biogeography, Southeast Asia.
\end{abstract}

\section{Introduction}

Wasps of the vespine genus Provespa Ashmead, 1903 are nocturnal and found new colonies as a swarm of workers accompanied by a single queen (Matsuura 1991). This genus, consisting of the three species $P$. anomala (Saussure, 1854), $P$. barthelemyi (Du Buysson, 1905), and P. nocturna Vecht, 1935, is distributed in southern Asia from eastern India in the west, through Indochina and southern China, to Sumatra, Borneo, and Java in the east.

Archer (2000) analyzed three morphological characters (apex of the aedeagus, tyloides of the male antenna, and anterior margin of the clypeus) of the three species of Provespa and proposed on this basis that the relationship among them could be expressed as $(P$. barthelemyi $+(P$. anomala $+P$. nocturna)). These three characters were those that "were found whose character states could be polarized by outgroup comparison" (Archer 2000: 127), but Archer did not specify any outgroup. He did summarize the distribution records of the three species and stated, referring to their phylogenetic relationships, that "the ancestor of Provespa first split into a mainland species ( $P$. barthelemyi) and an island species which later split into two species ( $P$. anomala and $P$. nocturna)."

In the present paper we conduct a cladistic analysis of Provespa based on both molecular and morphological data. Referring to these results and the historical ge- 
ography of the regions inhabited by these wasps, we also briefly reconsider the biogeography of the genus.

\section{Materials and Methods}

Specimens from which legs were taken for DNA extraction are deposited in the Natural History Collection of Ibaraki University, Mito, Japan (abbreviated as "IUNH"). Dried pinned specimens used in coding the morphological characters and those examined to add distribution records [we give only their localities and depositories here] are deposited in the IUNH, the Museum Zoologicum Bogoriense, Bogor, Indonesia (MZB), and the National Institute for Agro-Environmental Sciences, Tsukuba, Japan (NIAES).

The species included in our cladistic analyses were the three mentioned species of Provespa; four species of three other vespine genera (Vespa analis Fabricius, 1775, V. basalis Smith, 1852, Dolichovespula media (Retzius, 1783), and Vespula shidai Ishikawa, Yamane and Wagner, 1980); and two species of Polistes (Polistes chinensis antennalis Pérez, 1905 and $P$. japonicus Saussure, 1858) in the Polistinae, which according to Pickett and Carpenter (2010) is the sister group of the Vespinae. Polistes chinensis antennalis was used to root the trees.

\section{Morphological data}

The morphological characters given below, together with their states and codes (Table 1), were extracted from Carpenter (1987), Archer (1994, 2000), Carpenter and Perera (2006), and Pickett and Carpenter (2010). We observed their states on pinned and dried specimens under a stereoscopic microscope, except that the male genital characters were observed on dissected-out genitalia in glycerin under a stereoscopic microscope and/or observed with a scanning electron microscope (ABT 32, Topcon Technohouse) after coating with osmium by an osmium coater (Neoc-st, Meiwafosis). All characters were coded as additive unless "non-additive" is specified in parentheses after the character name.

Forewing

1. Prestigma length: prestigma shorter than pterostigma $=0$; prestigma longer than pterostigma, but less than 2.5 times longer $=1$; prestigma approximately three times or more longer than pterostigma $=2$

2. Length of first submarginal cell: shorter than distance from apex of cell to apex of wing $=0$; longer than this distance $=1$

3 Base of second submarginal cell: more or less angled, $\mathrm{M}$ oriented obliquely with respect to $\mathrm{m}$-cu1 $=0$; barely angled, $M$ oriented vertically $=1$

4 Placement of $\mathrm{m}$-cu2: close to $\mathrm{r}-\mathrm{m} 2=0$; distantly separated from $\mathrm{r}-\mathrm{m} 2=1$

\section{Hindwing}

5 Hamuli placement: beginning basad of fork of R1 and RS=0; beginning at this fork $=1$

6 Jugal lobe: present $=0$; absent $=1$

7 Axillary incision: present $=0$; absent $=1$

\section{Male antenna}

8 Tyloids (non-additive): narrow ridge or flattened rectangle $=0$; two on each flagellomere $=1$; absent $=2$ 

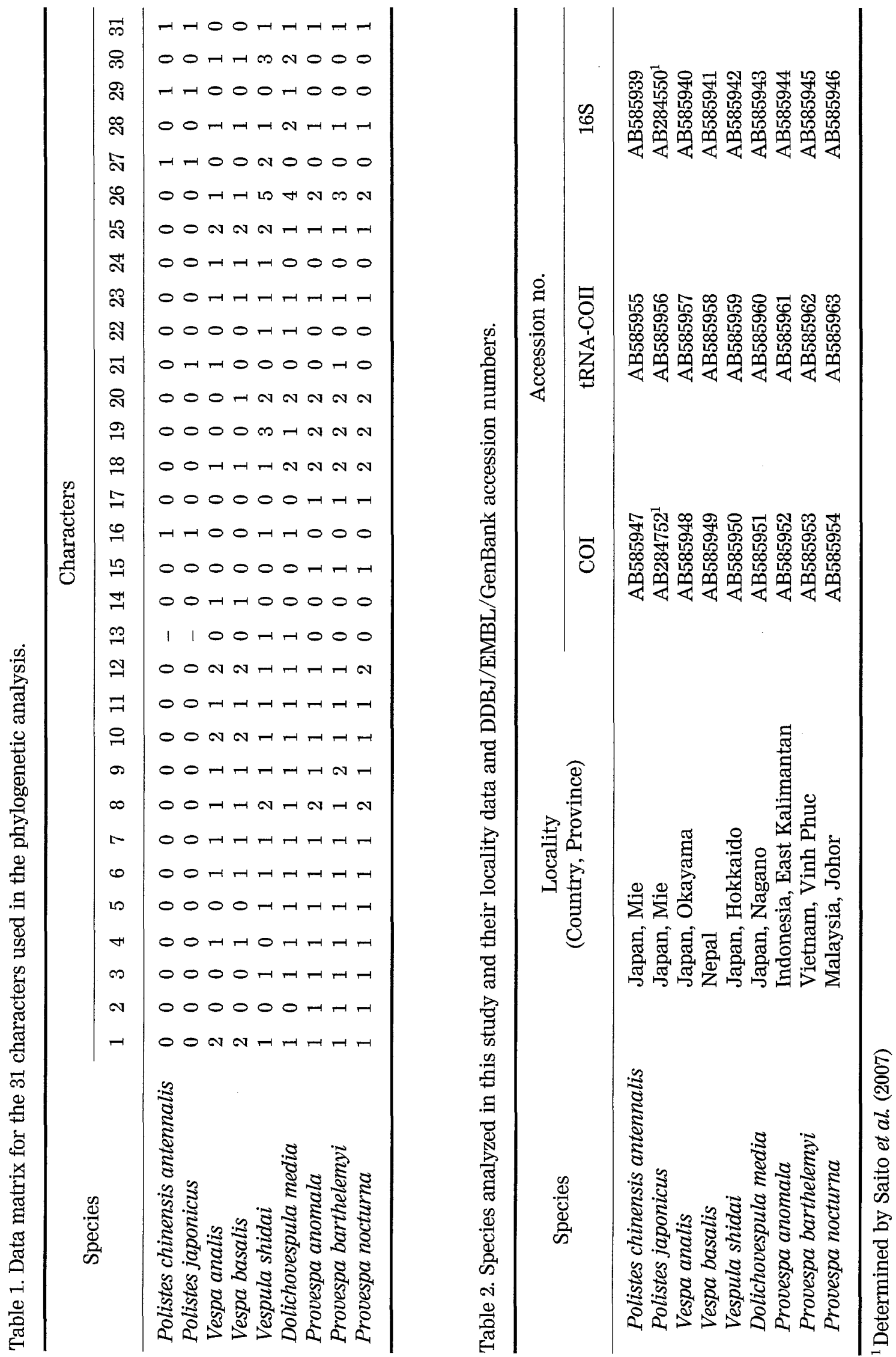


\section{Male head}

9 Apical margin of clypeus: convex $=0$; nearly straight or very shallowly emarginate medially $=1$; distinctly emarginate medially $=2$

\section{Female head}

10 Interantennal space: broad, rounded $=0$; triangular $=1$; strongly raised $=2$

11 Dorsal margin of clypeus: nearly straight $=0$; distinctly bisinuate $=1$

12 Apex of clypeus (Figs 1,2): pointed $=0$; shallowly emarginate $=1$; deeply emarginate $=2$

13 Clypeal lateroapical angles: blunt, rounded $=0$; triangular $=1$

14 Vertex length: ocelloccipital distance shorter than length of ocellar triangle $=0$; ocelloccipital distance longer than length of ocellar triangle $=1$

15 Ocelli: diameter less than distance between posterior ocellus and eye $=0$; diameter distinctly greater than this distance $=1$

16 Occipital carina (ventrally): reaching to base of mandible $=0$; effaced near mandibular base $=1$

17 Occipital carina (dorsally): present dorsolaterally $=0$; absent dorsolaterally $=1$

18 Mandibular teeth: pointed $=0$; with elongate cutting edge of less than twice length of apical part $=1$; with strongly elongate cutting edge of twice or more length of apical part $=2$

\section{Mesosoma}

19 Pronotal carina: complete $=0$; dorsally reduced $=1$; present only as lateral remnant $=2$; absent $=3$

20 Pretegular carina: complete $=0$; ventrally effaced $=1$; absent $=2$

21 Female scutum: distinctly longer than wide $=0$; nearly as wide as long $=1$

22 Scutal lamella: present $=0$; absent $=1$

23 Metanotal lobe: absent $=0$; present posteromedially $=1$

24 Hind coxal carina: absent $=0$; weak or as traces $=1$; present, strong $=2$

Male metasoma

25 Seventh tergum apex: rounded to straight $=0$; slightly emarginate $=1$

Male genitalia

26 Aedeagus apex (non-additive): little differentiated $=0$; transverse, projecting laterally $=1$; triangular $=2$; elongate $=3$; narrow $=4$; subcircular $=5$

27 Aedeagal apical indentation: deep $=0$; shallow $=1$; absent $=2$

28 Aedeagus width (non-additive): narrow throughout=0; as wide as or wider apically than at midlength $=1$; narrower apically than at midlength $=2$

29 Aedeagal medial lobes: absent $=0$; present $=1$

30 Paramere process (non-additive): absent $=0$; broadly inflected $=1$; pointed $=2$; finger-like $=3$

31 Digital apex projections: present $=0$; absent $=1$
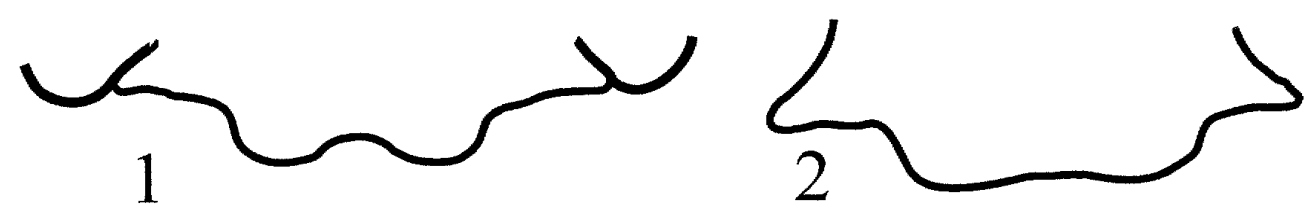

Figs 1, 2. Apical part of female clypeus. 1, Provespa nocturna; 2, Provespa anomala. 


\section{DNA sequencing}

Total DNA was extracted from one leg each of wasps preserved in $99 \%$ ethanol, by the standard phenol-chloroform method. For the amplification of each mitochondrial gene, the following primers for the polymerase chain reaction (PCR) were used. 1) The partial COI gene (1082 bp): LCO1490 (Folmer et al. 1994), HCO2198 (Folmer et al. 1994), Jerry (Simon et al. 1994), and COI-5 (5'-AATTGCAAATACTGCACCTATTGA-3', O. Kitade, pers. comm.). 2) The tRNALeu-partial COII gene ( 632 bp): E2 (Garnery et al. 1992) and COII1-2 (5'-ATTTTATACCACAAATTTCTGAACATTG-3', O. Kitade, pers. comm.). 3) The partial 16Sr-RNA gene ( $246 \mathrm{bp})$ : 16S-1221 and 16S-803 (Schmitz and Moritz 1998). The amplification of the target region was performed by a thermal cycler (PC808, ASTEC; GENIUS, TECHNE) in a reaction mixture $(50 \mu \mathrm{L})$ containing $10 \mathrm{mM}$ Tris- $\mathrm{HCl}, 50 \mathrm{mM} \mathrm{KCl}, 1.5 \mathrm{mM} \mathrm{MgCl}_{2}$, $2.5 \mathrm{mM}$ dNTP, $100 \mu \mathrm{M}$ of both primers, 1.0 unit of ExTaq polymerase (TaKaRa), and $1 \mu \mathrm{L}$ of genomic DNA solution. PCR conditions were set at $30 \mathrm{sec}$ for the initial denature, followed by 35 cycles of $30 \mathrm{sec}$ denature at $94^{\circ} \mathrm{C}, 1 \mathrm{~min}$ at $45^{\circ} \mathrm{C}$, and $3 \mathrm{~min}$ extension at $60^{\circ} \mathrm{C}$.

Sequencing was performed directly using the dideoxy termination method with dye-labeled terminations using BigDye Terminator v3.1 Cycle Sequencing Ready Reaction Kit (Perkin-Elmer) and run on an ABI PRISM 310 or 3130x Genetic Analyzer. The nucleotide sequences determined in the present study have been registered with DDBJ/EMBL/GenBank under the accession numbers AB585939AB585963 (Table 2).

\section{Phylogenetic analyses}

We amplified two fragments of the COI gene using two primer pairs, and then these two fragments were combined in the final matrix for phylogenetic analyses. Characters from 632 to 678 in the COI matrix were deactivated in the analyses as they included primer sequences (of HCO2198 and Jerry for 632-668) or many missing data (669-678).

The phylogenetic analyses were performed using the direct optimization method (Wheeler 1996) with POY 4.1.2 (Varón et al. 2010). The COI gene was analyzed as "prealigned", because it displayed no length variation. Tree searches were conducted using equal weights for all transformations (substitutions and insertion/deletion events). The following is the search strategy used in POY 4.1.2, in sequential order: build (all), swap (), select () [Initial Wagner trees were built by simply trying all possible addition positions for all terminals, and they were swapped using subtree pruning and regrafting (SPR) and tree bisection-reconnection (TBR) branch-swapping. Then, only the optimal and topologically unique trees were retained.] Character distributions in the morphological data were examined using WinClada ver. 1.00 .18 (Nixon 2002).

\section{Results}

\section{Phylogenetic analysis}

Analysis using adult morphological characters resulted in a single most parsimonious tree with a length of 61 (Fig. 3). The monophyly of the genus Provespa is supported by the length of the second submarginal cell of the forewing, i.e., longer 


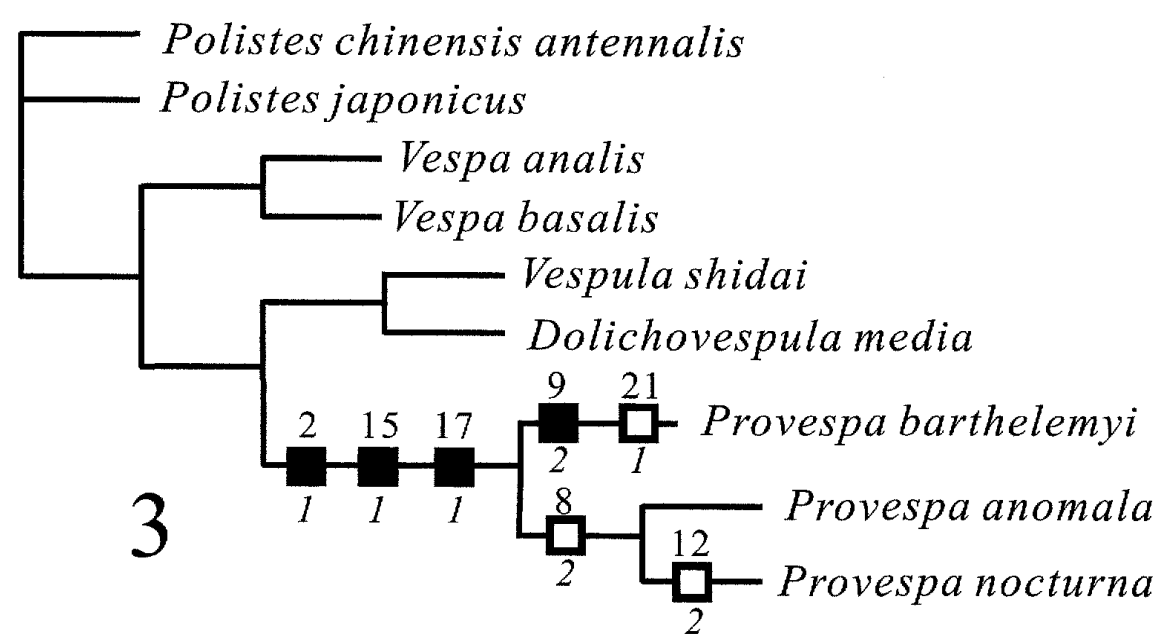

Polistes chinensis antennalis
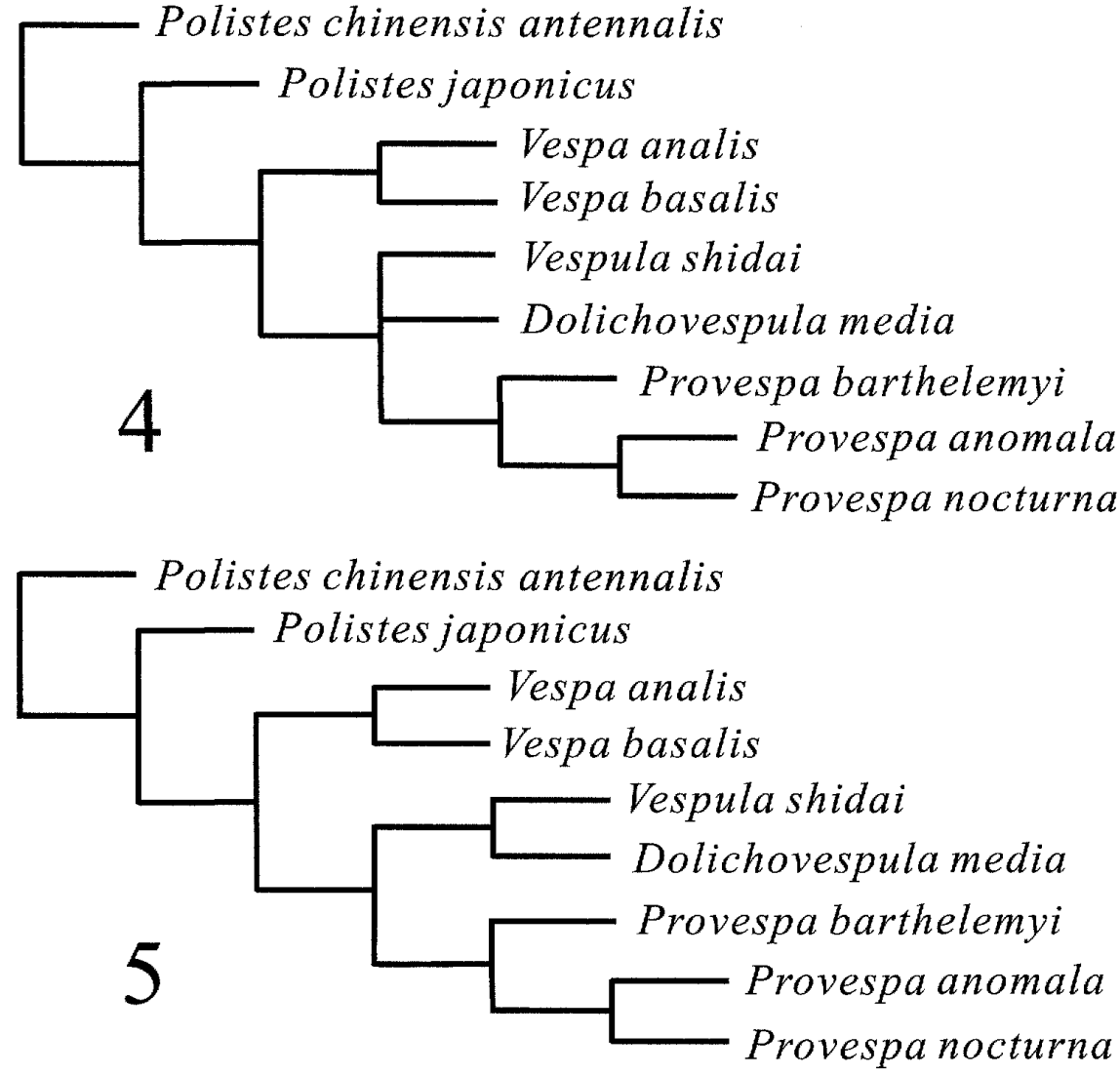

Figs 3-5. Trees resulted from different data sets. 3, Single most parsimonious tree $(\mathrm{L}=60$; $\mathrm{CI}=0.80 ; \mathrm{RI}=0.81$ ) based on morphological characters; characters apomorphic to Provespa and within Provespa clades are plotted (open squares indicate homoplasious states), with the character number above and the state below each square; 4 , strict consensus tree for two most parsimonious trees $(\mathrm{L}=1449)$ based on all molecular data (COI, COII, and 16S) combined; 5 , single most parsimonious tree $(L=1510)$ based on combined morphological and molecular data. 
than the distance from the apex of the cell to the apex of the wing (character \#2), the enlarged ocelli (\#15), and the dorsolateral effacement of the occipital carina (\#17). The resulting relationships among the three Provespa species were $(P$. barthelemy $i+(P$. anomala $+P$. nocturna $))$. The clade $P$. anomala $+P$. nocturna was supported only by the absence of tyloides of the male antennae.

Analyses based on the COI, tRNA-COII, and $16 \mathrm{~S}$ genes and on all molecular data combined returned two $(L=737)$, one $(L=521)$, one $(L=181)$, and two $(L=1449$, Fig. 4) most parsimonious trees, respectively. In all of the analyses using DNA sequence data, monophyly of Provespa was supported and the resulting relationships among the three species of Provespa were consistently expressed as ( $P$. barthelemyi $+(P$. anomala $+P$. nocturna $)$ ).

Direct optimization analysis based on combined morphological (31 characters) and molecular data ( $c a .1960 \mathrm{bp}$, including 47 deactivated in the analysis, see Materials and Methods) returned a single most parsimonious tree ( $\mathrm{L}=1510$, Fig. 5). This tree as well showed that Provespa is monophyletic and that the relationships among the three species are $(P$. barthelemyi $+(P$. anomala $+P$. nocturna $))$.

\section{Summary of distribution records of Provespa species}

Provespa anomala. The certain distribution records of this species are from the Peninsular Malaysia, Sumatra, Borneo, and Java (the type locality, though further details were not given in the original description) (Fig. 6). This species has also been recorded from India and Burma [Myanmar] (Bingham 1897; Dover and Rao 1922), but Vecht (1936: 159) pointed out that these records need confirmation and may have been based on misidentifications of Provespa barthelemyi. Additional distribution record: Java: Pago near Bandung in West Java [Jawa Barat] (NIAES).

Provespa barthelemyi. This species has been recorded from the southern part of the Asian continent, from eastern India to Indochina and the northern part of the Malay Peninsula (Fig. 6). Additional distribution records: Vietnam: Me Linh in Vinh Phuc Province (IUNH); Phu Tho Province (IUNH); Laos: Xam Neua in Houaphanh Province (IUNH).

Provespa nocturna. The distribution area of this species more or less overlaps that of $P$. anomala (Fig. 6), but it could be absent from Java.

There are two locality records far from the core distribution area. Vecht (1957: 9) listed a worker specimen (deposited in the Muséum Nationale d'Histoire Naturelle in Paris) labeled, "Tonkin, rég. de Hoa-Binh [northern Vietnam], 1929, leg. A. de Cooman", and Archer (1999) mentioned two females (deposited in the Hungarian Natural History Museum in Budapest) "found" at Edungalba, Queensland, Australia. Because they exhibit swarm founding (i.e., a colony is founded by workers accompanied by a queen), species of Provespa should have a much lower dispersal ability than independent-founding social wasps such as Polistes and Vespa, in which a colony is founded by one or a few inseminated (in temperate areas also overwintered) females. These last two distribution records of $P$. nocturna are thus likely to be based on erroneous labeling or on specimens found among goods in international trade. 


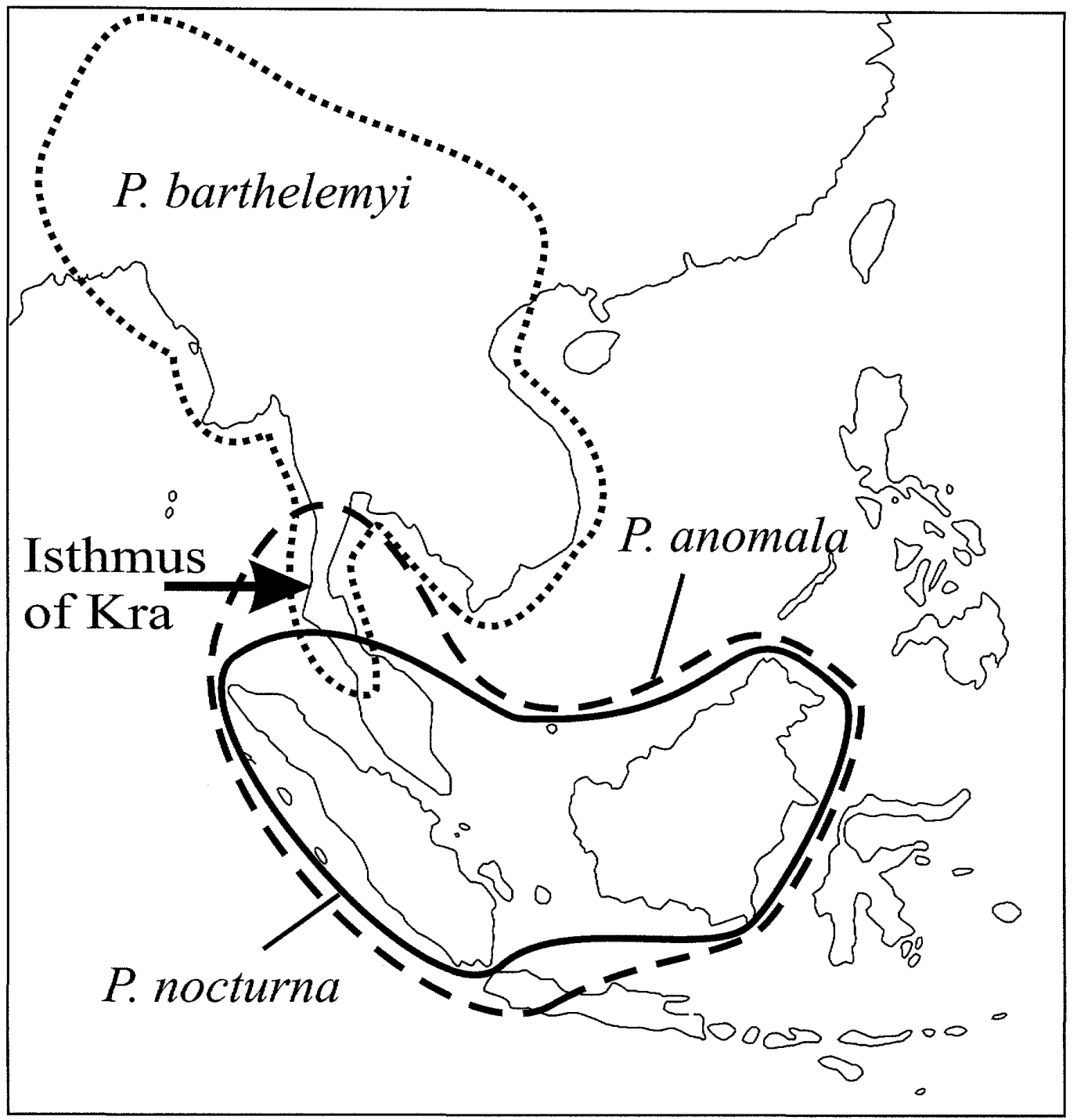

Fig. 6. Distribution patterns of the three species of Provespa. The solid line indicates distribution range of $P$. nocturna, the dotted line that of $P$. barthelemyi, and the broken line that of P. anomala.

\section{Discussion}

All of our analyses using different data sets (adult morphological characters; partial sequences of mitochondrial COI, COII, and 16S genes; and combined data) returned a monophyletic genus Provespa. All the analyses also resulted in the same topology for the relationships among the three species of Provespa, namely $(P$. barthelemyi $+(P$. anomala $+P$. nocturna $)$ ), which is the same as that of Archer's (2000) analysis. Archer (2000), however, did not mention how he rooted his unrooted phylogeny; the root is crucial for deductions on evolutionary processes, such as speciation and historical biogeography, based on phylogenetic relationships.

The distribution pattern (Fig. 6) and the species inter-relationships of 
Provespa lead us to infer, as Archer (2000) also assumed, that the speciation event that separated $P$. barthelemyi from the common ancestor of $P$. anomala and $P$. nocturna occurred as a single instance of vicariance around the Isthmus of Kra. The information currently available to us is insufficient, however, to propose a hypothesis on the process of speciation separating $P$. anomala and $P$. nocturna. For this, information on the genetic distances between local populations and detailed knowledge of the historical geography of Sunda Land is needed.

\section{Acknowledgments}

This study was partly supported by grants from the Japan Society for the Promotion of Science (FS: no. 08J03623; JK: no. 21570088). We thank R. Ubaidillah and $\mathrm{S}$. Yoshimatsu for arranging loans of specimens housed in the MZB and NIAES, respectively.

\section{References}

Archer, M. E. 1994. A phylogenetic study of the species of the genus Vespa (Hymenoptera: Vespidae). Entomologica Scandinavica 24: 469-478.

Archer, M. E. 1999. Provespa nocturna v. d. Vecht recorded from Australia and Paravespula shidai from Korea (Hym., Vespinae). Entomologist's Monthly Magazine 135: 90.

Archer, M. E. 2000. Taxonomy and distribution of the nocturnal hornets, Provespa (Hym., Vespinae). Entomologist's Monthly Magazine 136: 127-130.

Bingham, C. T. 1897. The Fauna of British India, including Ceylon and Burma. Wasps and Bees, Vol. 1. Hymenoptera. Taylor and Francis, London, xxix $+579 \mathrm{pp}$.

Carpenter, J. M. 1987. Phylogenetic relationships and classification of the Vespinae (Hymenoptera: Vespidae). Systematic Entomology 12: 413-431.

Carpenter, J. M. and Perera, E. P. 2006. Phylogenetic relationships among yellowjackets and the evolution of social parasitism. American Museum Novitates 3507: 1-19.

Dover, C. and Rao, H. S. 1922. A note on the diplopterous wasps in the collection of the Indian Museum. Journal and Proceedings of the Asiatic Society of Bengal (New Series) 18: 235-249.

Folmer, F. O., Black, M., Hoen, W., Lutz, R. and Vrijenhoek, R. 1994. DNA primers for amplification of mitochondrial cytochrome $c$ oxidase subunit I from diverse metazoan invertebrates. Molecular Marine Biology and Biotechnology 3: 294-299.

Garnery, L., Cornuet, J. M. and Solignac, M. 1992, Evolutionary history of the honey bee Apis mellifera inferred from mitochondrial DNA analysis. Molecular Ecology 1: 145-154.

Matsuura, M. 1991. Vespa and Provespa. Pp. 232-262. In: Ross, K. G. and Matthews, R. W. (Eds) The Social Biology of Wasps. Cornell University Press, Ithaca, NY.

Nixon, K. C. 2002. Winclada ver 1.00.18. Program and documentation. Bailey Hortorium, Cornell University, Ithaca, NY.

Pickett, K. M. and Carpenter, J. M. 2010. Simultaneous analysis and the origin of eusociality in the Vespidae (Insecta: Hymenoptera). Arthropod Systematics and Phylogeny 68: 3-33.

Saito, F., Kojima, J., Nguyen, L. T. P. and Kanuka, M. 2007. Polistes formosanus Sonan, 1927 (Hymenoptera: Vespidae), a good species supported by both morphological and molecular phylogenetic analyses, and a key social wasp in understanding the historical biogeog- 
raphy of the Nansei Islands. Zodogical Science 24: 927-939.

Schmitz, J. and Moritz, R. F. A. 1998. Molecular phylogeny of Vespidae (Hymenoptera) and the evolution of sociality in wasps. Molecular Phylogenetics and Evolution 9: 183-191.

Simon, C., Frati, F., Beckenbach, A., Crespi, B., Liu, H. and Flook, P. 1994. Evolution, weighting, and phylogenetic utility of mitochondrial gene sequence and a compilation of conserved polymerase chain reaction primers. Annals of the Entomological Society of America 87: 651-701.

Varón, A., Vinh, L. S. and Wheeler, W. C. 2010. POY version 4: phylogenetic analysis using dynamic homologies. Cladistics 26: 72-85.

Vecht, J. van der 1936. Some further notes on Provespa Ashm. (Hym., Vespidae). Journal of the Federated Malay States Museums 187: 159-166.

Vecht, J. van der 1957 The Vespinae of the Indo-Malayan and Papuan areas (Hymenoptera, Vespidae). Zoologische Verhandelingen 34: 1-82.

Wheeler, W. C. 1996. Optimization alignment: the end of multiple sequence alignment in phylogenetics? Cladistics 12: 1-9. 